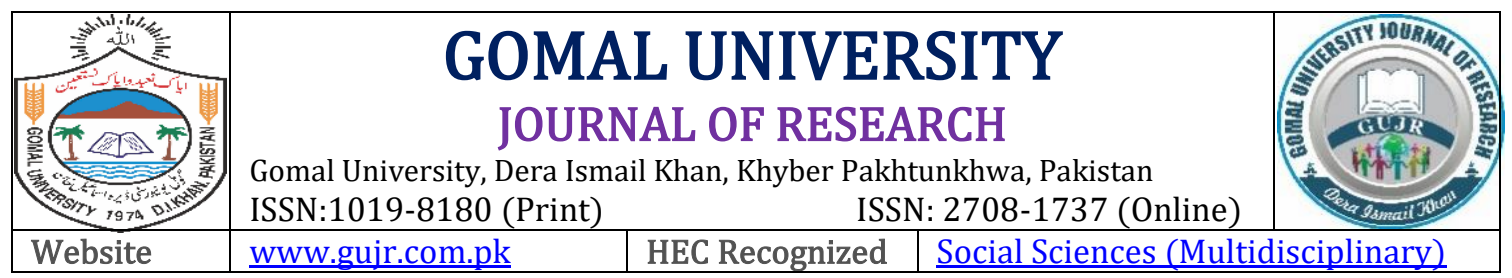

\title{
OIL PRICES MOVEMENTS AND INDUSTRY STOCK RETURNS: EVIDENCE FROM PAKISTAN STOCK EXCHANGE (PSX)
}

\author{
Muhammad Asif ${ }^{1}$, Sharif Ullah Jan $^{2}$ \& Shahid Iqbal ${ }^{3}$ \\ ${ }^{1}$ Assistant Professor, City University of Sciecnce and Information Technology, Peshawar, Pakistan \\ ${ }^{2}$ Lecturer Management Sciences, FATA University, TSD Dara, NMD Kohat, Pakistan \\ ${ }^{3}$ Senior Lecturer, Riphah International University Islamabad, Pakistan
}

\begin{tabular}{|c|c|}
\hline ARTICLE INFO & ABSTRACT \\
\hline $\begin{array}{l}\text { rds: } \\
\text { turns, Returns } \\
\text {, Oil Prices } \\
\text { ion, Pakistan } \\
\text { change }\end{array}$ & \multirow{2}{*}{$\begin{array}{l}\text { The recent financial and economic recessions have chiefly increased } \\
\text { the importance of risk management and forecasting for business } \\
\text { firms. Capital markets being the main pillar of economy are affected } \\
\text { the most in such circumstances. The current study has attempted to } \\
\text { investigate the impact of oil prices on the returns and volatility of } \\
\text { Pakistani listed firms using the GARCH }(1,1) \text { model. Furthermore, this } \\
\text { relationship has been investigated by categorizing the existing sectors } \\
\text { of the Pakistan Stock Exchange (PSX) into oil producers, oil users, and } \\
\text { oil substitutes for the period from January } 2015 \text { to December } 2019 \text {. } \\
\text { The findings of the study highlighted some strong evidence regarding } \\
\text { the oil price movement and the firms' returns across these sectors. } \\
\text { Interestingly, firms' returns behave differently about the magnitude } \\
\text { of significance and direction of symbols based on their nature of the } \\
\text { industry. Therefore, it is suggested for future studies to consider the } \\
\text { nature of the sector of oil while exploring the relationship between oil } \\
\text { prices and stock returns. } \\
\text { (9) \& \& } 9020 \text { Gomal University Journal of Research }\end{array}$} \\
\hline $\begin{array}{l}\text { Article History: } \\
\text { Date of Submission: } \\
\text { 16-08-2020 } \\
\text { Date of Acceptance: } \\
\text { 20-03-2021 } \\
\text { Date of Publication: } \\
\text { 31-03-2021 }\end{array}$ & \\
\hline Corresponding Author & Muhammad Asif: asifbaloch@cusit.edu.pk \\
\hline DOI & \\
\hline
\end{tabular}

\section{INTRODUCTION}

The capital market is considered one of most important pillars of the economy and it plays a major role in economic stability. However, the volatility of the stock market can hardly affect the whole economy and can be seen as one of the important factors for economic stability. The root causes of market volatility remain different in various countries and conditions, however, oil price variation is considered one of the most influential factors out of others (Nguyen \& Tran, 2020). The contemporary economies either developed or developing have shown a substantial correlation with oil price movements (Al-Khazali \& Mirzaei, 2017). This relation becomes even more crucial if the economy is a major oil producer or importer. The oil price variation affects all the macroeconomic factors of any country, however; its effect is prominent at the micro-level too. For instance, due to the recent oil price movements, the financial performance of firms' cash flows was heavily affected 
and in turn, their stock prices and retained earnings were heavily reduced (Elyasiani, Mansur \& Odusami, 2011). Similarly, some studies highlighted different effects of oil prices across various sectors. However, oil price variation could be a big issue specifically for oil-related firms, such as oil producers, oil users, and oil substitutes. It is worth mentioning that despite importance of oil price movements in determining firm's stock returns across industries, very little empirical work has been found concerning these factors in Pakistani context. In this connection, the Pakistan Stock Exchange has shown strong correlation with international crude oil price movements. However, this relation remains hazy at sectoral level and needs to be investigated about industry's origin and nature.

It is worthy to know that how oil prices affect the stock returns of aforementioned sectors differently for some reasons. Firstly, the increasing globalization has made the correlation stronger than ever before among various stock markets, and limited cross-market diversification opportunities are leftover for the investors which ultimately increased sectoral level diversification prospects in the same economy (Masood, Tvaronavičienè \& Javaria, 2019). Secondly, diversification across sectors concerning oil effects has generated arbitrage chances among aggressive investors and speculators. Thirdly, the oil effects on different sectors have shown dissimilar impacts that triggered researchers to not only consider the market level returns but also the sectoral level returns (Pal \& Mitra, 2019). Finally, it is empirically proven that investors always want higher returns for holding higher risks and that would not be possible without considering the sectoral level returns against the oil prices. What distinguishes this study from existing one that instead of traditional regression models this study used the GARCH $(1,1)$ model which has advantage to resolve stationarity and autocorrelation issues with an inbuilt mechanism in a more efficient manner than the manual techniques. Secondly, most of the studies explored oil price impact on the entire stock market, however, the current study focused on more comprehensive industries (Aggarwal \& Manish, 2020). Only three major categories of oil users (construction, chemical, transportation, etc.) oil producers (oil extractors and refineries, etc.), and oil alternatives (coal, gas, electric) are selected to truly represent the impact of oil price variation.

\section{LITERATURE REVIEW}

Different economists had developed various statistical measures to capture the ever-changing nature of market volatility. William Sharpe (1964) analyzed that variation of that individual stock return is based on aggregate market movements, considering the market as a composite of various individual firms. Still, (Masood et al., 2019) realized that other than cumulative firms movement, market volatility link with various economic activities and level of inflation. Meanwhile, after the oil price shocks of 1979-80, researchers realized important link between macroeconomic stability with oil price variation. For the first time, the importance of oil was realized in production (Petrol, etc.) and consumption (heating oil) and it was noticed that high oil price also boosts the level of inflation specifically in oil-importing countries (Jebran, Chen, Saeed \& Zeb, 2017). Therefore, the impact of oil price movements on stock returns has been extensively explored in a decade. However, most of these studies are limited to developed economies such as US, Canada, and European countries or other major oil-importing economies. A decade spent for incorporating oil price shock into macroeconomic models and various econometrics techniques have been applied to test the theoretical relation of oil price shocks with macroeconomic. For instance, Malik and Umar (2019) used causality and co-integration analysis to measure nonstationary behavior of exchange rate and real oil prices. Study confirmed long-run effect of oil price shocks even if market remains perfect in long-run.

Whereas, Kaneko and Lee (1995) used VAR model to analyzed oil price effects on US and Japanese markets. The considered variables of the study were risk premium, excess stock returns, growth 
rate, and oil price change. Also, Diaz and Gracia (2014) conducted study on developed countries using 23 years of data considering risk premium, rate of inflation, and exchange rate as explanatory variables. They concluded that oil price change influences the stock market negatively. However, in the context of the developing and emerging economies, limited empirical work has been done so far. For instance, researchers studied the variation of Indonesian market with oil price change using the LVAR model. The study confirmed direct relation between industry returns with both short and long-term oil markets. Similarly, Antonakakis, Cunado, Filis, Gabauer and Gracia (2020) used large data set of forty years (including structural breaks) concluded a short-term and positive association between oil prices and stock returns. While the study of Nazir and Hameed (2015) suggested that oil price movements show different characteristics in different situations. If the economy is in boom and there is variation in the oil market it's enforced equity output, and if there is a depression period it shows demoralize results on equity output. Youssef and Mokni (2019) investigated oil-importing and exporting countries and assessed that stock market of oil-importing countries remain sensitive to oil price fluctuation and any fluctuation in oil market has a vital symmetric effect on that country capital market. Still, it affects oil-exporting countries differently, its impact is diverse on different sectors in the different movement of oil market i.e. upward or downward in short as well as in long run.

Antonakakis et al. (2020) collected the cumulative nature sample including developed, developing, oil-importing, and oil-exporting economies. The study concluded that oil price variation influences major economic indicators of the oil-importing countries such as inflation, foreign reserves, cost of productions, and interest rates. On contrary, same price changes had opposite (favorable) effects on the same indicators of exporting countries. Moreover, they also oil prices have more significant impacts on the stock returns of the selected sample countries. Antonakakis et al. (2020) analyzed examine implied volatility amid oil price and four diverse asset classes which are stock, commodity, exchange rate, and macroeconomic condition. They suggest that oil price implied volatility is highly correlated with the stock market but least correlated with the exchange rate so investor can hedge portfolio accordingly. The movements in crude oil prices greatly affected oil-importing economies and Pakistan is one of them. As the movement in the oil market creates instability in determining general prices and also shows the impact of stock prices. In this regards an investigation was done by Kelikume and Muritala (2019) to the determined volatility spillover effect of world oil prices on Pakistan stock market using weekly data of last fifteen years. They used the AGARCH model and conclude that unexpected oil shocks have a significant effect on stock returns. The cited literature shows a significant effect of an oil price change on stock market and micro and macro-economic variables. Moreover, crude oil price variation negatively affects oil-importing countries and oilconsuming industry while its out-turn remain positive for oil-exporting economies and oil-producing firms.

\section{Hypotheses of Study}

Based on reviewed literature of objectives of study, authors have set following hypotheses for this study:

H1: There is the significant impact of the oil price movements on the stock returns movements.

H2: The oil price movements have a varying effect on stock returns depending upon affiliation of firms i.e. oil substitute, oil producer, and oil user.

\section{Theoretical Framework}

From the existing literature in the field of stock returns, the most prominent models are CAPM and Fama and French (1992). These models have defined various conventional determinants of stock returns such as the market premium (from CAPM and FAMA and FRENCH), the size premium, 
and the value premium (FAMA and FRENCH). However, the aforementioned literature has evident that stock returns are linked with oil price fluctuations too. The literature suggests that increases in oil prices lead to an increase in stock returns of oil-producing firms while it reacts opposite is the case of oil using firms. Therefore, this study considered all three factors of the Fama \& French model and two additional factors i.e. oil return and volatility to analyze the stock return of the selected sector.

\section{Figure 1}

Theoretical Framework

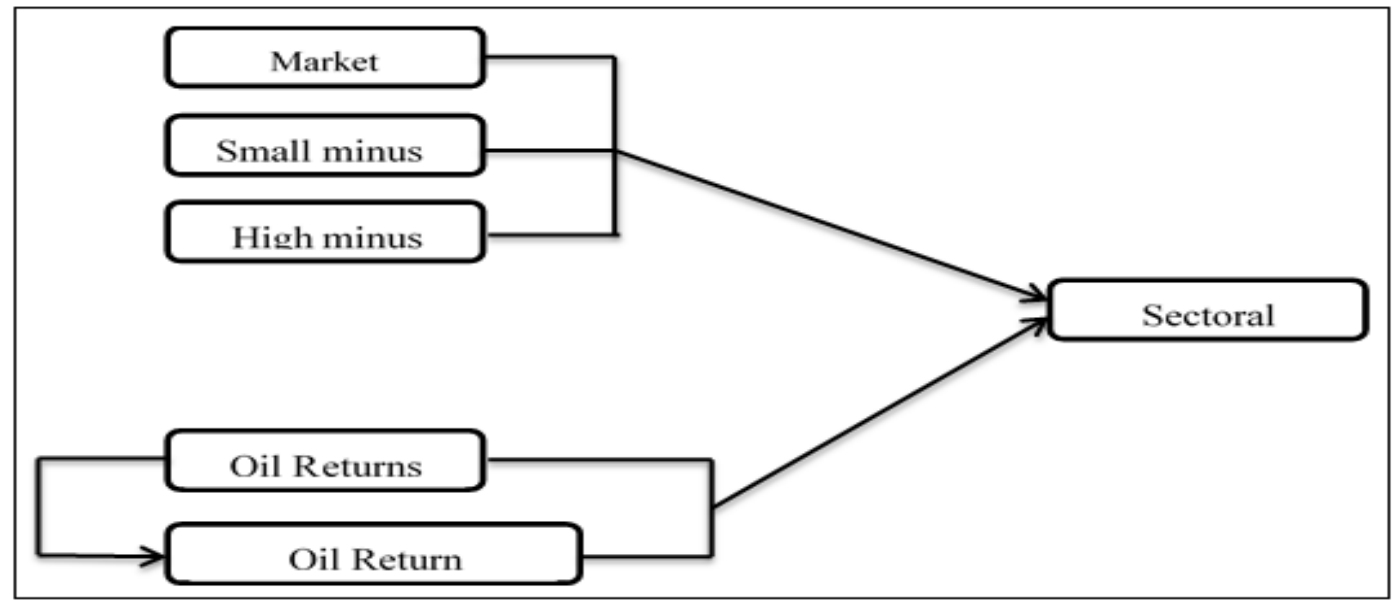

\section{ANALYTICAL PROCESS, DATA,AND METHODOLOGY}

In this section, the analytical process, variables of study, data, and methodology of study have been explained.

\section{Analytical Process for Sampling}

Keeping in view the nature and objectives of the study, the "purposive" sampling technique was considered as the best-suited technique for data collection. As the authors were mainly concerned with those firms (from the three sectors) having effects on their stock returns due to oil price movements. To explore oil price changes' effect on the stock returns of oil producers, oil users, and oil substituting firms, this study analyzed monthly basis data for the last five years starting from January 2015 to December 2019. All the reliable resources were accessed for data including the PSX official website, the business recorder website, and the paid source of opendoors.com. After the final screening of the data, the stock returns of only fifty firms were finalized 1 (as these were the only firms in given categories where the contiguous returns were available without missing values). Besides, all the symbols and full titles of the firms were also extracted from the Pakistan Stock Exchange official portal. For the calculation of the market capitalization, the size of the firms was used.

\section{Study Variables}

The existing financial literature shows that researchers have used a variety of determinants to explain the stock returns movement. In this connection, Sathyanarayana, Harish and Gargesha,

\footnotetext{
${ }^{1}$ Though around 600 firms were found to be listed on the starting date of the sample period i.e. January 1 , 2015; however, only 50 firms were fulfilling the pre-decided criteria of the study.
} 
(2017) indicated that among others the market returns, oil prices, and interest rates remained the most significant factors for determining stock returns. Similarly, Chatziantoniou, Degiannakis and Filis (2019) reported that stock returns are determined significantly by market returns, size and value of firm along with oil price change. Therefore, following the existing theoretical and empirical literature current study also applied the historically proven model to determine the stock returns along with oil prices in diverse situation. In this linking, this study used three factors of the Fama and French model that is excess return, size, and value of the firm and addition with oil prices and volatility.

\section{Analysis of Data}

In this study to achieve the objective of study the collected data was arranged concerning the three mentioned categories. To analyze the nature and characteristics of the data, a summary of statistics was measured which includes the ADF and PP tests to estimates stationarity of the time-series data. After confirming stationary nature of data size and value of firms were measured followed by oil return and volatility. Finally, measured variables were applied in GARCH to summarized results of study.

\section{Statistical Equation of GARCH $(1,1)$}

In line with the existing financial literature, this study applied GARCH $(1,1)$ model to analyze given regression between sectoral return and independent variables. The time-series data follow random walk which may create an issue while estimating on linear models and generally such data suffers from stationarity and autocorrelation problems, while GARCH family models have inbuilt ability to deal with such issues. Nonetheless, model of this study also suggests looking for volatility impact in oil sector, so, as of all these logical justifications, this study finalized GARCH $(1,1)$ model as most appropriate one, following Elyasiani et al. (2011) technique. General format of GARCH $(1,1)$ is as follows:

Here,

$$
\sigma_{n}^{2}=\gamma V_{L}+\alpha u_{n-1}^{2}+\beta \sigma_{n-1}^{2}
$$

$\sigma_{n}^{2}=$ volatility of day "n"; $\gamma$ =weight assigned to $\mathrm{VL}$; VL=long-run average variance rate

$\alpha$ =weight assigned to $\mu 2 \mathrm{n}-1 ; \mu 2 \mathrm{n}-1=$ previous day return (u2n-1); $\beta$ =weight assigned to

$\sigma_{n-1}^{2}$ and

$\sigma_{n-1}^{2}=$ previous day variance $(\sigma 2 n-1)$.

The above equation is a general equation and this study would modify this equation in order to incorporate the other variables of the study as follow:

$$
\mathrm{ERt}=\beta \mathrm{o}+\beta_{1} \mathrm{RMt}+\beta_{2 \mathrm{SMBt}}+\beta_{3} \mathrm{HMLt}+\beta_{4} \mathrm{ROt}-1+\beta_{5} \mathrm{CVOt}-1+\varepsilon \mathrm{t} . \ldots . . . \text { (2) }
$$

The equation (2) is generated with a "O" mean and a constant variance. Moreover, here'

ERt $=$ Industry stock return, calculated as: $=\ln \left(\frac{R t}{R t-1}\right)$

Where, $\ln$ is the natural logarithm; Rt is the current price; and Rt-1 is the previous price.

$\mathrm{RM}=$ Return of Market, calculated as: $=\ln \frac{(K S E-100 \text { index }) t}{(K S E-100 \text { index }) t-1}$

Where, ln is the natural logarithm; (KSE-100 index)t is the current price index; and (KSE-100 index)t-1 is the previous price index

SMB = Small Minus Big

HML = High Minus Low 


$$
\begin{array}{ll}
\text { ROt } & =\text { Monthly returns of oil price } \\
\text { CVO } & =\text { Conditional Volatility of oil returns }
\end{array}
$$

The variance equation from the above mean equation is explained as follows:

$$
\begin{aligned}
& \mathrm{Ht}=\mathrm{ao}+\mathrm{a} 1 \varepsilon 2 \mathrm{t}-1+\mathrm{a} 2 \mathrm{ht}-1+\mathrm{a} 3 \text { CVORt-1.. } \\
& \text { Here, a1 = ARCH (the short-term shocks); } \\
& \mathrm{a} 2=\mathrm{GARCH} \text { (the long-term shocks); } \\
& \mathrm{a} 3=\text { mean equation regressor }
\end{aligned}
$$

As a first step of the analysis, all three factors of Fama \& French along with oil return and volatility were added to $\operatorname{GARCH}(1,1)$ and were estimated for all the 50 firms. The effect of their variables on sectoral return was captured for each month. Therefore, this exercise was repeated for each firm independently to get the coefficient values. The findings from this step indicated significant effects of the oil prices on the returns of the 34 firms out of 50 that are further elaborated in the discussion section.

\section{RESULTS AND DISCUSSION}

In the following sections, all results acquired from descriptive statistics and GARCH $(1,1)$ models are reported along with detailed discussion and interpretations. But, separate results on factor of Fama \& French model are given with sufficient discussion in appendixes A, B, and C at end of this paper.

\section{Descriptive Statistics}

The summary statistics are estimated for each firm in each sector separately, presented in following tables, which highlight the outliers in data. For the normality characteristics of the data Jarque Bera (JB) test is applied while stationarity of the data has been deducted through unit root test including Augmented Dickey-Fuller (ADF) and Phillips-Perron (PP) test. For serial correlation, Q-statistics were applied and Kurtosis and Skewness of data are provided over these statistics. All values are given concerning specific significance level i.e. $90 \%, 95 \%$, and 99\%, duly indicated with ***, **, and $*$ respectively.

\section{Table 1}

Descriptive Statistics (Oil Substitute Sector)

\begin{tabular}{cccccccccc}
\hline Symbol & Mean & SD & SKW & KU & JB & ADF & PP & LQ(12) & LQ2(12) \\
\hline APL & 0.0266 & 0.1841 & 2.1393 & 10.523 & $184.1294^{*}$ & -1.0328 & -1.0328 & $113.61^{*}$ & $50.330^{*}$ \\
MARI & 0.01313 & 0.0628 & 0.5068 & 4.3128 & $6.7628^{* *}$ & -0.9133 & -0.9133 & $162.01^{*}$ & $273.54^{*}$ \\
OGDC & 0.0213 & 0.1195 & 1.7478 & 7.75052 & $85.518^{*}$ & -1.2020 & -0.9133 & $187.68^{*}$ & $335.65^{*}$ \\
POL & 0.0250 & 0.0827 & 1.5785 & 8.50145 & $98.9067^{*}$ & -1.1290 & -1.1291 & $113.61^{*}$ & $50.330^{*}$ \\
PPL & 0.0208 & 0.0987 & 2.1381 & 9.83917 & $159.941^{*}$ & -1.0181 & -1.0181 & $148.10^{*}$ & $442.83^{*}$ \\
PRL & 0.0068 & 0.1111 & 0.3457 & 3.50338 & 1.7984 & -1.5678 & -1.0462 & $160.33^{*}$ & $27.176^{*}$ \\
PSO & 0.0282 & 0.2632 & -0.2747 & 7.66827 & $55.2365^{*}$ & -1.2641 & -1.2642 & $146.47^{*}$ & $298.14^{*}$ \\
\hline SHEL & 0.0183 & 0.0851 & 0.4609 & 3.7367 & $3.4233^{*}$ & -0.8794 & -0.8795 & $193.71^{*}$ & $664.03^{*}$ \\
\hline
\end{tabular}

The above table shows descriptive statistics of eight firms from oil substitute sector. Mean values for all firms remain positive which shows bullish trend in stock market for these firms. Moreover, the highest mean stock return is $2.8 \%$ of PSO whereas the biggest variance value is $26.3 \%$ against the same stock indicating that market follows the risk and return theory. Seven firms out of eight are positively skewed while PSO is data is skewed on negative side. Moreover, most firms' Kurtosis value remains greater than its threshold value which is 3 . The values of Jarque-Bera test remained significant for entire sector of oil substitute i.e. data did not show normality for stock returns. Also, 
stationarity is checked over ADF and PP and its values are given at a 99 percent significance level in table.

Table 2

Descriptive Statistics (Oil Producer Sector)

\begin{tabular}{cccccccccc}
\hline Symbol & Mean & SD & SKW & KU & JB & ADF & PP & LQ(12) & LQ2(12) \\
\hline BPL & 0.0265 & 0.1841 & 2.1393 & 10.5228 & $184.1294^{*}$ & $-1.0328^{*}$ & $-1.0328^{*}$ & $119.95^{*}$ & $386.93^{*}$ \\
HUBC & 0.0131 & 0.0628 & 0.5068 & 4.3127 & $6.7628^{*}$ & $-0.9133^{*}$ & $-0.9133^{*}$ & $137.20^{*}$ & $347.10^{*}$ \\
KOHE & 0.0213 & 0.1195 & 1.74782 & 7.7505 & $85.518^{*}$ & $-1.2020^{*}$ & $-0.9133^{*}$ & $93.160^{*}$ & $166.66^{*}$ \\
NCPL & 0.0249 & 0.0827 & 1.5785 & 8.5014 & $98.9067^{*}$ & $-1.1290^{*}$ & $-1.1290^{*}$ & $131.02^{*}$ & $253.86^{*}$ \\
NPL & 0.0208 & 0.0987 & 2.1381 & 9.8391 & $159.941^{*}$ & $-1.0181^{*}$ & $-1.0181^{*}$ & $211.75^{*}$ & $304.54^{*}$ \\
SNGP & 0.0068 & 0.1111 & 0.3457 & 3.5033 & 1.7984 & $-1.5678^{*}$ & $-1.0462^{*}$ & $119.95^{*}$ & $386.93^{*}$ \\
SSGC & 0.0282 & 0.2632 & -0.2747 & 7.6682 & $55.2365^{*}$ & $-1.2641^{*}$ & $-1.2641^{*}$ & $227.42^{*}$ & $410.94^{*}$ \\
\hline SEL & 0.0183 & 0.0850 & 0.4609 & 3.7367 & $3.4233^{*}$ & $-0.8794^{*}$ & $-0.8794^{*}$ & $91.160^{*}$ & $161.66^{*}$ \\
\hline
\end{tabular}

Above table 2 shows that firms in oil-producing sectors are identified with positive average returns. Here again, the highest average returns are associated with the highest standard deviation for SSGC firm i.e. the average return for this firm is $2.88 \%$ on monthly basis with the largest standard deviation i.e. $26.32 \%$. This proves the risk-premium theory about this sector as well. Interestingly, the least average returns of HUBC are also associated with the least standard deviation of the same firm that is $1.3 \%$ and $6.28 \%$ respectively. Moreover, in this sector, out of eight firms, seven are identified with positives skewed. The KU values of the entire sector happen to be greater than three just like the previous sector. While the $\mathrm{PP}$ and ADF test all the values remain significant for this sector.

Table 3

Descriptive Statistics (Oil Users Sector)

\begin{tabular}{|c|c|c|c|c|c|c|c|c|c|}
\hline Symbol & Mean & SD & SKW & $\mathrm{KU}$ & JB & $\mathrm{ADF}$ & PP & $\mathrm{LQ}(12)$ & LQ2(12) \\
\hline ATBA & 0.0332 & 0.1512 & 2.3605 & 14.5464 & 382.5391* & $-0.9603^{*}$ & $-0.9603^{*}$ & $134.55^{*}$ & $170.55^{*}$ \\
\hline AGIL & 0.0280 & 0.1716 & 3.3192 & 19.283 & $760.1266^{*}$ & $-1.2179 *$ & $-1.2179 *$ & $107.44^{*}$ & $228.33^{*}$ \\
\hline ATLH & 0.0248 & 0.1016 & -0.4603 & 5.4925 & $17.35671^{*}$ & $-1.2438^{*}$ & $-1.2438^{*}$ & $328.32^{*}$ & $362.01^{*}$ \\
\hline ACPL & 0.0217 & 0.1041 & 0.8893 & 3.7937 & $9.3260^{*}$ & $-1.0465^{*}$ & $-1.0465^{*}$ & $310.84^{*}$ & $490.48^{*}$ \\
\hline BWHL & -0.2533 & 2.6149 & 1.2512 & 13.5622 & $289.6474^{*}$ & $-0.9258 *$ & $-0.9259 *$ & $316.11^{*}$ & $410.22 *$ \\
\hline BERG & 0.0418 & 0.1913 & 0.9037 & 4.2788 & $12.0510^{*}$ & $-1.1134^{*}$ & $-1.2438^{*}$ & $111.31^{*}$ & $454.15^{*}$ \\
\hline BUXL & 0.0402 & 0.2404 & 2.7408 & 14.546 & $395.8679 *$ & $-1.3436^{*}$ & $-1.0859 *$ & $71.332^{*}$ & $104.96^{*}$ \\
\hline BWCL & -0.2533 & 2.6149 & 1.2512 & 13.5622 & $289.6474 *$ & $-0.812^{*}$ & $-0.812^{*}$ & $147.48^{*}$ & $160.00 *$ \\
\hline CHCC & 0.0466 & 0.1621 & 1.0466 & 5.9501 & $32.1661^{*}$ & $-1.1334^{*}$ & $-1.1334^{*}$ & 74.941* & $290.64^{*}$ \\
\hline DCL & -0.0035 & 0.0364 & 1.3567 & 5.7539 & 36.7433* & $-1.2059 *$ & $-1.206^{*}$ & 78.209* & 86.488* \\
\hline EXIDE & 0.0882 & 0.7079 & 5.7465 & 39.919 & $3675.583^{*}$ & $-1.0514^{*}$ & $-1.0514^{*}$ & 136.34 * & 194.03* \\
\hline EMCO & -0.0039 & 0.2812 & -1.1214 & 6.4928 & $42.3585^{*}$ & $-0.8194^{*}$ & $-0.8194^{*}$ & $111.60^{*}$ & 183.08* \\
\hline FCCL & 0.0404 & 0.1329 & 0.9443 & 4.1614 & $12.0850^{*}$ & $-1.0208^{*}$ & $-1.0208^{*}$ & $138.43^{*}$ & $185.80 *$ \\
\hline FECTC & 1.4983 & 0.3279 & 6.9710 & 6.1212 & 6331.683* & $-1.0541^{*}$ & $-1.0542^{*}$ & 49.190* & $374.22 *$ \\
\hline FLYNG & 0.0436 & 0.2178 & 2.3063 & 9.73007 & $163.6541^{*}$ & $-0.8873^{*}$ & $-0.8874^{*}$ & 37.123 & $85.202^{*}$ \\
\hline GHNL & 0.1367 & 0.4779 & 2.3852 & 10.2177 & $184.0127 *$ & $-0.6903^{*}$ & $-1.4016^{*}$ & 80.201 & 87.560 \\
\hline GAMON & 0.1208 & 0.6480 & 5.5078 & 4.4301 & $3340.772 *$ & $-1.1700^{*}$ & $-1.1700^{*}$ & $117.30^{*}$ & $152.78^{*}$ \\
\hline GWLC & 0.0413 & 0.2022 & 0.7173 & 3.7943 & $6.6117^{* *}$ & $-1.3709 *$ & $-1.3710^{*}$ & $26.356^{*}$ & $148.50^{*}$ \\
\hline GAIL & 0.0216 & 0.1589 & 0.6819 & 4.7085 & $11.7487^{*}$ & $-1.0084^{*}$ & $-1.0084^{*}$ & $22.356^{*}$ & 140.50 \\
\hline HCAR & 0.1213 & 0.5613 & 5.0135 & 32.4208 & $2375.054^{*}$ & $-1.1991 *$ & $-1.1992 *$ & $278.20^{*}$ & $411.00 *$ \\
\hline INDU & 0.0433 & 0.2384 & 3.3790 & 19.6988 & $797.7796^{*}$ & $-1.3014^{*}$ & $-1.3014^{*}$ & $203.14^{*}$ & $329.49 *$ \\
\hline ICI & 0.0372 & 0.1970 & 1.9031 & 9.452 & $137.963^{*}$ & $-1.5364^{*}$ & $-1.2279 *$ & $156.30^{*}$ & $256.05^{*}$ \\
\hline $\mathrm{KOHC}$ & 0.0753 & 0.1927 & 1.0446 & 4.9433 & $20.0144^{*}$ & $-0.9820 *$ & $-0.9821^{*}$ & $123.43^{*}$ & $302.74 *$ \\
\hline LUCK & 0.0372 & 0.1068 & 1.5131 & 7.4651 & $183.6485^{*}$ & $-1.1791^{*}$ & $-1.1791^{*}$ & $200.94^{*}$ & $200.94 *$ \\
\hline MLCF & 0.0501 & 0.2233 & -0.8159 & 4.7085 & $194.9541^{*}$ & $-0.7832^{*}$ & $-0.7833^{*}$ & $60.897^{*}$ & $227.17^{*}$ \\
\hline
\end{tabular}




\begin{tabular}{cccccccccc} 
PICT & 0.0296 & 0.1144 & 1.5191 & 7.4651 & $71.7063^{*}$ & $-0.9225^{*}$ & $-0.9226^{*}$ & $117.19^{*}$ & $213.90^{*}$ \\
PIOC & 0.0610 & 0.2149 & 1.6768 & 7.4642 & $76.6420^{*}$ & $-0.9330^{*}$ & $-0.9452^{*}$ & $205.34^{*}$ & $280.10^{*}$ \\
PNSC & 0.0307 & 0.1997 & 1.9179 & 9.1572 & $129.371^{*}$ & $-1.0399^{*}$ & $-1.0095^{*}$ & $148.18^{*}$ & $208.62^{*}$ \\
PSEL & 0.0343 & 0.1837 & 2.1986 & 10.347 & $180.234^{*}$ & $-1.2099^{*}$ & $-1.21^{*}$ & $200.94^{*}$ & $200.94^{*}$ \\
PSMC & 0.0562 & 0.2542 & 2.9232 & 16.3993 & $525.4022^{*}$ & $-1.4178^{*}$ & $-1.4178^{*}$ & $184.34^{*}$ & $279.42^{*}$ \\
SAZEW & 0.0143 & 0.1334 & 1.3919 & 7.8711 & $77.3821^{*}$ & $-0.8281^{*}$ & $-0.8281^{*}$ & $179.99^{*}$ & $215.06^{*}$ \\
STCL & 0.0152 & 0.1890 & 1.4773 & 7.4820 & $70.8460^{*}$ & $-1.5180^{*}$ & $-1.518^{*}$ & $158.00^{*}$ & $263.38^{*}$ \\
\hline THCCL & 0.0093 & 0.1181 & 0.8679 & 4.5487 & $13.3053^{*}$ & $-1.3671^{*}$ & $-1.3672^{*}$ & $102.51^{*}$ & $102.51^{*}$ \\
\hline
\end{tabular}

The above table represents those firms that use oil for their operations. Out of the total of 34 firms in this sector, only four firms produced negative mean returns while the rest of the firms generate positive mean returns again a sign of a bullish trend in this sector. Interestingly, the highest values of standard deviations are found to be associated with the negative mean return of that firm... Moreover, again all the firms have Kurtosis values greater than three. As for the normality test is concerned, it is evident that the values for JB tests were insignificant for only two firms, which means that the values for the rest of the firms are not normally distributed except these two firms. While the value of both ADF and PP (used for stationarity) showed highly significant values for all the firms. Finally, Q-statistics also exhibited that the values of firms are independent of their past values.

\section{GARCH Model Results}

Each sector's results model is briefly elaborated below GARCH $(1,1)$ was applied on every single firm's data of whole sector. Oil-producing sector consists of eight firms and symbols of each firm are given in first column.

\section{Table 4}

GARCH Results (Oil Producer Sector)

\begin{tabular}{ccccccccc}
\hline Firm & C & HML & OPR & RM_RF & SMB & OPV & ARCH & GARCH \\
\hline APL & $-0.0286^{* *}$ & 0.0041 & 0.0736 & $0.5413^{* *}$ & -0.0215 & $0.0321^{* *}$ & $1.0790^{*}$ & 1.1156 \\
MARI & -0.0533 & -0.0003 & $-0.5844^{*}$ & $1.9408^{*}$ & 0.1289 & $0.0664^{* * *}$ & $2.2228^{*}$ & $2.3912^{*}$ \\
OGDC & 0.0456 & 0.0095 & -0.0107 & -0.1722 & 0.0458 & -0.0493 & $-0.1163^{*}$ & $0.6417^{*}$ \\
POL & -0.0219 & -0.0073 & $0.1774^{* *}$ & $0.6901^{*}$ & $-0.0806^{* * *}$ & 0.0247 & 0.3325 & 0.8180 \\
PPL & $-0.0310^{* *}$ & 0.0110 & $0.3027^{*}$ & $0.9415^{*}$ & -0.0438 & 0.0150 & $0.7626^{* *}$ & 0.7718 \\
PRL & 0.0532 & 0.0006 & 0.0996 & -0.1008 & -0.1989 & -0.0611 & $0.5799^{*}$ & $1.1300^{*}$ \\
PSO & -0.0159 & -0.0049 & -0.0886 & $1.4428^{*}$ & $0.1234^{* * *}$ & 0.0101 & 0.2516 & 0.6342 \\
\hline SHEL & 0.0118 & 0.0417 & 0.0394 & $1.3040^{*}$ & $0.3183^{*}$ & -0.0308 & $3.0569^{*}$ & 3.0555 \\
\hline
\end{tabular}

In the above table, column "C" represents the constant term of GARCH $(1,1)$ while the subsequent column the HML reports the High minus Low value of the firms. Next to this, the OPR stands for Oil Price Returns which is computed by taking the price fluctuation effect over the study period. For this particular column, merely 3 companies have significant outcomes i.e. MARI with -0.5844 showing that a one-unit increase in oil price would lead to a 0.58 unit decrease in the firm's returns and vice-versa. The next importance of the study is "RM-RF" and it values remained significant for six out of eight firms (except OGDCL and PRL). Out of those six significant firms, MARI came up with the highest coefficient shows that it return varies around $194 \%$ due to change in the market returns. The subsequent firms PSO, SHELL, PPL, and POL have shown considerable change due to changes in the market returns i.e. 144\%, 130\%, 94\%, and 69\% respectively. Consequently, more particularly, the study results reported this variable (RM-RF) as the most significant among others showing substantial effect about $75 \%$ i.e. six out of eight firms in this sector. In this connection, the next column Small minus Big (SMB)and only three firms have shown significant results for this determinant. 
These firms included SHELL, PSO, and POL with coefficient values of $0.318,0.123$, and -0.0806 respectively. The values of oil return volatility are shown in the next column and out of the entire sector its value remains significant only for two firms. The coefficient values of APL and MARI are 0.032 and 0.066 shows that a unit increases in oil prices would lead to increased return volatility increase $3.2 \%$ of APL and $6.6 \%$ of MARI. Furthermore, the ARCH coefficient values present the short-term price shock significant for the majority of firms except for two POL and PSO. The OGDCL is being the only firm having a negative coefficient in this case that is -0.1163. The highest coefficient value for this factor is 3.055 associated with SHELL showing its returns are highly effective by short-term price fluctuation. The lowest positive values are 0.579 for PRL as the returns of this firm are affected by short-term shock around 57\%. The value of GARCH is represented in the final column of this table which represents the long-term shock. In this connection, its value remained significant for MARI, OGDCL, and PRL and its coefficient values are 2.39, 0.64, and 1.13 respectively. In other words, these three firms are affected by the long-term shocks due to oil price volatility.

Table 5

GARCH Result (Oil Substitute Firms)

\begin{tabular}{ccccccccc}
\hline Firm & C & HML & OPR & RM-RF & SMB & OPV & ARCH & GARCH \\
\hline BPL & -0.0012 & $0.1228^{*}$ & 0.2976 & $1.3089^{*}$ & $0.2535^{* * *}$ & -0.0372 & $0.4859^{*}$ & 0.3597 \\
HUBC & 0.0024 & 0.0124 & -0.0087 & $0.3278^{* *}$ & 0.0280 & 0.0041 & $-0.1698^{* *}$ & $0.9760^{*}$ \\
KOHE & 0.0802 & 0.0187 & $0.2898^{*}$ & 0.024 & 0.0211 & -0.0790 & $-0.1238^{*}$ & $0.9294^{*}$ \\
NCPL & -0.0018 & 0.0123 & 0.1306 & $0.7466^{*}$ & 0.0150 & 0.0136 & $-0.1520^{*}$ & $1.0074^{*}$ \\
NPL & 0.0109 & 0.0259 & -0.1553 & $0.9849^{* *}$ & 0.0832 & -0.0070 & -0.0669 & 0.0762 \\
SNGP & -0.0278 & -0.0151 & $-0.3883^{* *}$ & $1.6340^{*}$ & 0.0186 & 0.0080 & -0.1320 & $1.0158^{*}$ \\
SSGC & -0.0471 & -0.0169 & $-0.3670^{* * *}$ & $0.8901^{* *}$ & -0.0081 & 0.0560 & $0.4553^{*}$ & 0.8665 \\
\hline SEL & -0.0078 & 4.0704 & -0.0534 & $0.6732^{* *}$ & 0.0124 & 0.0184 & -0.1421 & 0.4273 \\
\hline
\end{tabular}

Above table 5 shows the results of the oil substitute group which consisted of the eight firms. The coefficient of constants remained insignificant for the entire sector. For the value variable, only one firm is found significant which is BPL and its value shows that a one-unit change in oil prices will bring about a $12.2 \%$ change in its stock returns. Moreover, its positive sign indicates its parallel movement with the oil market. The next factor is OPR that indicates oil price changes affect the dependent variable. For this variable three out of eight firms KOHE, SNGPL, and SSGC have shown significant impact over the industry stock returns with coefficient values of $0.289,-0.388$, and 0.367 respectively. All these firms have shown the significance concerning this variable on a 90\% confidence interval. For the rest of the firms, this factor remains insignificant. Next, the oil market returns represented by RM-RF showed a significant effect for most of the firms except one that is KOHE. More specifically the highest value for this variable is produced by SNGPL which is 1.634 and the lowest one by HUBC 0.327. For other firms, this variable explains $130 \%$ change in BPL, $94 \%$ change in NPL, 89\% change in SSGC, $67 \%$ change in the SEL, and $74 \%$ change in NCPL stock returns.

In sum, the findings from this table present that this is the most important variable in explaining the variation in stock returns of almost $90 \%$ of the firms. As for the size, the factor is concerned, it showed very low significance for firms' returns and only one firm (BPL) in this sector remain significant and its value remained significant at a 90\% confidence interval. Unfortunately, the next oil price volatility variable was found insignificant for the whole sector. Finally, the value of the ARCH column is significant for almost all the firms. However, it is interesting that the values for this factor remained negative for majority of firms. While in GARCH column only 4 firms amongst 
the others have shown significant coefficients i.e. 0.976, 0.929, 1.007, and 1.015 for HUBC, KOHE, NCPL, and SNGPL respectively. These indicate that the firms' returns are affected by the long-term shocks.

Table 6 GARCH Result (Oil Users Firms)

\begin{tabular}{|c|c|c|c|c|c|c|c|c|}
\hline Symbol & $\mathrm{C}$ & HML & OPR & $\mathrm{Rm}-\mathrm{Rf}$ & SMB & OPV & ARCH & GARCH \\
\hline ATBA & 0.0635 & 0.0353 & 0.1799 & 0.9059 & $0.2069^{*}$ & -0.0549 & 0.3569 & 0.8583 \\
\hline AGIL & -0.0137 & 0.0400 & 0.0709 & $0.8500^{*}$ & $0.2616^{*}$ & 0.0174 & $0.9511^{* *}$ & 1.1376 \\
\hline ATLH & 0.0471 & -0.0001 & 0.0517 & 1.1637 & 0.0183 & -0.0382 & $-0.0825^{*}$ & 0.4481 \\
\hline ACPL & -0.0100 & 0.0009 & 0.1013 & $0.9624 *$ & 0.05557 & 0.0319 & $0.0555^{* *}$ & 0.0875 \\
\hline BWHL & -0.0391 & $-0.1665^{* *}$ & 0.0103 & 0.4414 & $-1.1006^{*}$ & -0.0176 & $9.4642 *$ & 9.4642 \\
\hline BERG & 0.0241 & -0.0007 & $0.435^{* * *}$ & $1.7027 *$ & 0.0316 & -0.0379 & $-0.1276^{*}$ & $1.0071^{*}$ \\
\hline BUXL & 0.0172 & $0.0841^{*}$ & -0.1847 & $1.5257^{*}$ & $0.4193^{*}$ & -0.0138 & $1.2302^{*}$ & 1.2009 \\
\hline BWCL & 0.0942 & 0.0475 & 0.1699 & 0.2999 & 0.0844 & -0.0941 & $-0.1282^{*}$ & $0.9761^{*}$ \\
\hline CHCC & $0.0839 * *$ & 0.0432 & -0.0743 & $1.3342^{*}$ & 0.0376 & $0.0963^{* *}$ & 0.5615 & 0.8250 \\
\hline DCL & -0.0061 & 0.0019 & 0.1033 & -0.1454 & -0.0056 & 0.0087 & -0.0745 & 0.4798 \\
\hline EXIDE & 0.0354 & $0.0503^{*}$ & -0.0728 & $1.1918^{*}$ & $0.2096^{* *}$ & -0.0021 & $5.1408^{*}$ & $5.3723^{*}$ \\
\hline EMCO & -0.0525 & -0.0023 & -0.0539 & 0.7772 & 0.1319 & $0.0589^{* *}$ & 0.0436 & 1.1487* \\
\hline FCCL & $0.0513^{* *}$ & 0.0053 & -0.2173 & 1.3839* & 0.0976 & $-0.0488^{*}$ & $-0.1965^{* *}$ & $0.9574^{*}$ \\
\hline FECTC & -0.0963 & $2.0038^{*}$ & -1.4156 & 5.1083 & 1.2297 & $0.2283^{*}$ & $-0.0946^{*}$ & $1.0784^{*}$ \\
\hline FLYNG & -0.0064 & 0.0308 & 0.3048 & $2.2617^{*}$ & 0.2887 & 0.0284 & $-0.0845^{* *}$ & $0.7973^{*}$ \\
\hline GAIL & -0.0395 & 0.0016 & -0.1534 & 0.7942 & 0.0095 & 0.0373 & -0.1636 & $0.9820^{*}$ \\
\hline GAMON & $0.2352 *$ & $0.1472^{*}$ & -0.0877 & $1.9716^{*}$ & $0.8803^{*}$ & $-0.2291^{* *}$ & $1.4717^{*}$ & 1.4611 \\
\hline GWLC & 0.0071 & 0.0093 & 0.1740 & $1.1981^{*}$ & 0.0840 & 0.0070 & 0.9918* & $1.4612^{*}$ \\
\hline GHNL & -0.0198 & -0.0518 & $-0.5134 *$ & $1.4149^{*}$ & -0.2351 & 0.0532 & $-0.0930 *$ & $0.9509 *$ \\
\hline HCAR & 0.0462 & -0.0031 & -0.0827 & $1.6665^{*}$ & -0.0310 & -0.0225 & $1.7845^{*}$ & $2.1270^{*}$ \\
\hline INDU & 0.0086 & -0.004 & 0.2140 & $1.1259^{*}$ & -0.0038 & 0.0020 & $1.6800^{* *}$ & $1.9392 *$ \\
\hline ICI & -0.0193 & -0.0142 & -0.1557 & $0.7730^{* *}$ & $-0.1747^{* * *}$ & 0.0359 & $0.5847^{* *}$ & $1.2034^{*}$ \\
\hline $\mathrm{KOHC}$ & $0.2102 *$ & 0.0983 & 0.2044 & 0.3657 & $0.2482^{*}$ & $-0.1855^{*}$ & $0.5993^{* *}$ & 0.4359 \\
\hline LUCK & 0.0297 & -0.011 & 0.0785 & $0.6493^{*}$ & 0.0145 & -0.0149 & $0.7339^{*}$ & -0.0003 \\
\hline MLCF & 0.0182 & 0.0156 & 0.5114 & 1.0010 & 0.0274 & 0.0045 & -0.1158 & $0.6267^{* *}$ \\
\hline PICT & 0.0678 & 0.0166 & 0.0979 & $1.1546^{*}$ & 0.1200 & -0.0648 & $-0.0885^{* *}$ & 0.0552 \\
\hline PIOC & 0.0346 & 0.0162 & -0.2789 & $2.0987^{*}$ & $0.2372^{*}$ & -0.0279 & $1.0895^{*}$ & 1.0937 \\
\hline PNSC & -0.0440 & 0.0120 & -0.2653 & $1.7915^{*}$ & 0.1354 & 0.0405 & 0.2824 & $0.8726^{* *}$ \\
\hline PSEL & 0.0177 & 0.0165 & $-0.2958^{* *}$ & $0.8222^{*}$ & $0.2505^{*}$ & -0.0033 & $1.6601^{*}$ & 1.5916 \\
\hline PSMC & $0.0617^{* *}$ & 0.0008 & 0.0564 & $0.9408^{*}$ & -0.0483 & -0.0422 & $2.0175^{*}$ & 2.0109 \\
\hline SAZEW & -0.0273 & $0.0227^{*}$ & -0.0099 & 0.476 & 0.0410 & 0.0201 & $-0.0898^{*}$ & 0.9699* \\
\hline STCL & -0.0153 & 0.0214 & 0.2944 & 0.7162 & 0.0745 & 0.0103 & $0.6263^{* *}$ & 0.6739 \\
\hline THCCL & 0.0267 & 0.0155 & 0.1818 & -0.0616 & 0.1074 & -0.0236 & 0.1676 & $0.8588^{*}$ \\
\hline
\end{tabular}

The above table 6 presents the GARCH $(1,1)$ results for the firms in the oil user sector which consist of thirty-four firms. For the GARCH constant, five firms are found with significant coefficient values including CHCC, FCCL, GAMON, KOHE and PSMC while the rest of firms have shown insignificant coefficients. The value column has five firms with significant coefficients while the rest of the firms remained insignificant. Amongst those significant firms, the highest value is produced by FECTC which is 2.003, while the lowest value is associated with SAZEW. The coefficient value for FECTC shows that it brings about $200 \%$ positive changes in the stock returns. While the negative value associated with BWHL shows opposite side thr variation firm's stock returns. Moreover, only three firms have shown significant results for OPR which is $43.5 \%$ for BERG, $-51.3 \%$ for GHNL, and 29.5\% for PSEL at 90\%, 95\%, and 99\% significance levels. The RM - RF was found significant for 21 firms in the entire sample. Among these, the highest coefficient values are 2.261 for FLYING and the lowest for LUCK which is 0.649 . The oil market returns have proved to be the most important factor in this study and around 66\% of firms have shown variations in returns associated with RM $-\mathrm{RF}$. 
The next variable is small minus big (SMB) which explains the size factor of firms. Unfortunately, this variable did not show any significant contribution. The next variable OPV appeared significant for six firms out of total. These six firms include CHCC with $9.6 \%$ and EMCO with $5 \%$ variations in returns against this variable. The ARCH was significant for most of firms among which nine firms were found with negative signs and rest with positive signs. The final column in table presents the long-term shock or GARCH parameter for which fifty percent of the firms have shown a significant positive impact on their stock returns. There is at least fifty percent of the firms which stock returns are affected by the long term shocks. Among these firms, highest value is found to be 9.46 or $946 \%$ variation in sector's stock returns since of variation in oil price market. Nonetheless, all these firms have shown positive values for this parameter and there is no single firm with a negative value. Therefore, it can be interpreted that the long term shocks always affected these firms in positive directions.

\section{DISCUSSION}

Particularly in the last decades, a substantial interest of the financial researchers has been observed in the area of oil price and stock return relationships due to the oil crises of 1979-80. Moreover, oil is the most frequently traded commodity and has witnessed major fluctuations in recent years too and it has crucial importance for the macro as well as micro indicators of an economy. The fluctuations in the oil prices can majorly affect the financial market along with the macro economy. Hence current study aimed to investigate the impact of oil price changes on the stock returns at the sectoral level which can be categorized as oil users, oil producers, and oil substitutes (Abhyankar, Xu \& Wang, 2013). For this purpose, based on cited literature current study considered oil return and oil price volatility along with the excess return, size, and value as main determinants of sectoral stock return. Furthermore, keeping in view the nature of the study and characteristics of time series this study applied the GARCH $(1,1)$ model to analyze the said relationship. The results of this study are in line with existing financial literature in this area which is done by Pakistani and international authors. For instance, finding of the study suggests that among other stock returns, oil substitute firms are highly associated with oil price fluctuation. These results are in line with findings of Pal and Mitra (2019), Malik and Umar (2019), Jebran et al. (2017), Elyasiani et al. (2011) and Ahmed, Kashif and Irfan (2017). Besides, finding of all traditional factor change with oil prices are partially similar with Kelikume and Muritala (2019), Sakaki (2019) and Al-hajj, Al-Mulali and Solarin (2020) who found some of factors adjustment with oil price fluctuations. While these are partly dissimilar with the findings of Jebran et al. (2017), Sathyanarayana et al. (2017), and Masood et al. (2019). However, these results remained contradictory with the some studies too e.g. Ayoubi and Rezaei (2016), Vveinhardt, Streimikiene, Ahmed, Ghauri and Ashraf (2017), Singhal et al. (2019), and Aggarwal and Manish (2020), it may be reason for contextual difference and data period or model differences.

\section{CONCLUSION}

The recent financial and economic recession have chiefly increased importance of risk management and forecasting. Capital markets being the main pillar of an economy are affected the most in such circumstances. The current study has attempted to investigate impact of oil prices on the returns and volatility of Pakistan listed firms using the GARCH $(1,1)$ model. Furthermore, this relationship has been investigated by categorizing the existing sectors of PSX into oil producers, oil users, and oil substitutes. The findings of the study highlighted some strong evidence regarding the oil price movement and the firms' returns across these sectors. Interestingly, the firms' returns behave differently concerning the magnitude of significance and direction of symbols based on their nature of the industry. Therefore, it is suggested for future studies to consider the nature of the sector concerning oil while exploring the relationship between oil prices and stock returns. The increased 
fluctuation in the financial market has increased the importance of portfolio management and risk evaluation. Oil is considered one of the major ingredients for the economy and can affect the earning of various connecting sectors. Therefore, the current study aimed to investigate the impact of recent oil price fluctuations on the stock returns of various groups such as oil users, oil producers, and oil substitutes. Along with oil price as the major determinant this study also included the traditional stock return determinants including the market excess return, value, and size factors of the firm.

Only fifty listed firms in Pakistan Stock Exchange fulfilled the pre-decided criteria and the GARCH model was applied to the data based on the nature of time-series and various diagnostic tests to get the best results from analysis. The monthly stock returns of the selected firms were collected from January 2015 to December 2019. The study reported significant effects of all the traditional factors along with the oil price change. Interestingly, the results were different for all three sectors. More precisely, the number of firms found significant was highest among oil substitutes followed by oil producers and oil users. Also, out of fifty firms around, two-third were found significant in all three sectors. More particularly, eighty-seven percent of the firms in the oil substitute sector were found positive and significant. The positive sign of their coefficients indicates an upward trend in oil price will lead them to appreciate their stock prices. Same trend was exhibited by the oil-producing firms with seventy-five percent significant results show that both moved in same direction. For third and final sector i.e. oil users, sixty-two percent of firms show significant results and again all them were positive.

\section{Recommendations}

This study has analyzed oil price variations' impact on stock price movements while the future study can consider oil price impact on stock price volatility. Moreover, only three sectors were considered in the current study while further studies should enlarge this figure to evaluate its impact on other sectors. Investors, arbitrageurs, and hedgers who invest in firms can utilize knowledge of firm's return sensitivities to oil price volatility for risk management strategies and related strategic decision. Firms, can secure position over various future contracts especially when oil volatility giving early warning signals.

\section{REFERENCES}

Abhyankar, A., Xu, B., \& Wang, J. (2013). Oil price shocks and the stock market: evidence from Japan. The Energy Journal, 34(2).

Aggarwal, P., \& Manish, M. K. (2020). Effect of oil fluctuation on stock market return: An empirical study from India. International Journal of Energy Economics and Policy, 10(2), 213.

Ahmed, F., Kashif, M., \& Irfan, M. Z. (2017). Long-Run Relationship between Oil Price and Macroeconomic Indicators using Johansen Co-integration Test: A Case of Pakistan. RADS Journal of Social Sciencess \& Business Management, 4(1), 79-95.

Al-hajj, E., Al-Mulali, U., \& Solarin, S. A. (2020). Exploring the Nexus Between Oil Price Shocks and Sectoral Stock Returns: A New Evidence from Stock Exchange in Malaysia. Economic Change and Restructuring, 1-19.

Antonakakis, N., Cunado, J., Filis, G., Gabauer, D., \& de Gracia, F. P. (2020). Oil and asset classes implied volatilities: Investment strategies and hedging effectiveness. Energy Economics, 104762.

Ayoubi, S., \& Rezaei, F. (2016). A Study on the Effect of Oil Price Variations on Stock Returns under Environmental Uncertainty (Sales). Bulletin de la Société Royale des Sciences de Liège, 85, 1080-1089.

Chatziantoniou, I., Degiannakis, S., \& Filis, G. (2019). Futures-based forecasts: How useful are they for oil price volatility forecasting? Energy Economics, 81, 639-649. 
Diaz, E. M., \& de Gracia, F. P. (2017). Oil price shocks and stock returns of oil and gas corporations. Finance Research Letters, 20, 75-80.

Elyasiani, E., Mansur, I., \& Odusami, B. (2011). Oil Price Shocks and Industry Stock Returns. Energy Economics, 33(5), 966-974.

Fama, E.F., and French, K.R., (1992). The Cross-Section of Expected Stock Returns. The Journal of Finance, 47, (2), 427-465

Jebran, K., Chen, S., Saeed, G., \& Zeb, A. (2017). Dynamics of Oil Price Shocks and Stock Market Behavior in Pakistan: Evidence from the 2007 Financial Crisis Period. Financial innovation, 3(1), 1-12.

Kelikume, I., \& Muritala, O. (2019). The Impact of Changes in Oil Price on Stock Market: Evidence from Africa. International Journal of Management, Economics and Social Sciences (IJMESS), 8(3), 169-194.

Malik, F., \& Umar, Z. (2019). Dynamic Connectedness of Oil Price Shocks and Exchange Rates. Energy Economics, 84, 104501.

Masood, O., Tvaronavičienè, M., \& Javaria, K. (2019). Impact of Oil Prices on Stock Return: Evidence from G7 Countries. Insights into Regional Development, 1(2), 129-137.

Mork, K. A. (1989). Oil and the macroeconomy when prices go up and down: an extension of Hamilton's results. Journal of political Economy, 97(3), 740-744.

Nazir, S., \& Hameed, T. (2015). Impact of Oil Price and Shocks on Economic Growth of Pakistan: Multivariate Analysis (Sectoral Oil Consumption). Business and Economics Journal, 6(4), 1.

Pal, D., \& Mitra, S. K. (2019). Oil Price and Automobile Stock Return Co-Movement: A wavelet Coherence Analysis. Economic Modelling, 76, 172-181.

Sakaki, H. (2019). Oil Price Shocks And The Equity Market: Evidence for the S\&P 500 Sectoral Indices. Research in International Business and Finance, 49, 137-155.

Sathyanarayana, S., Harish, S. N., \& Gargesha, S. (2017). Volatility in Crude Oil Prices and its Impact on Indian Stock Market Evidence from BSE Sensex\#. In International Conference on Emerging Trends in Finance, Accounting and Banking, SDMIMD.

Sathyanarayana, S., Harish, S., \& Gargesha, S. (2017). Volatility in Crude Oil Prices and its Impact on Indian Stock Market Evidence from BSE Sensex. In International Conference on Emerging Trends in Finance, Accounting and Banking, SDMIMD.

Singhal, S., Choudhary, S., \& Biswal, P. C. (2019). Return and volatility linkages among International crude oil price, gold price, exchange rate and stock markets: Evidence from Mexico. Resources Policy, 60, 255-261.

Vveinhardt, J., Streimikiene, D., Ahmed, R. R., Ghauri, S. P., \& Ashraf, M. (2017). Asymmetric influence of oil and gold prices on Baltic and South Asian stock markets: Evidence from Johansen cointegration and ARDL approach. Acta Montanistica Slovaca, 22(4).

Youssef, M., \& Mokni, K. (2019). Do Crude Oil Prices Drive the Relationship between Stock Markets of Oil-Importing and Oil-Exporting Countries? Economies, 7(3), 70.

Zulfiqar, M., Hamid, K., Kashif Khurshid, M., Usman Khurram, M., \& Yasir Saeed, M. (2018). Sensitivity Analysis of Macroeconomic Forces and Sectoral Returns: Evidence from Energy and Textile Sectors of Pakistan. European Online Journal of Natural and Social Sciences: Proceedings, $7(3$ (s)), pp-189. 